\title{
Determinants of Capital Structure in India (1990-1998): A Dynamic Panel Data Approach
}

\author{
Basudeb Guha-Khasnobis \\ The United Nations University \\ Saumitra N. Bhaduri
}

Indian Council for Research on International Economic Relations

\begin{abstract}
Conventional wisdom on capital structure choices has been by and large confined to the United States and a few advanced countries having institutional similarities. In this paper we make an attempt to provide some insight into the capital structure choice of developing countries through a case study of the Indian corporate sector. We develop a dynamic panel data model that explicitly takes into account the possibility of adjustment cost to reach optimal capital structure. The results suggest that restructuring cost is important in adjustment towards an optimal capital structure. We identify the key determinants of the speed of adjustment towards optimal capital structure and also highlight important differences across cohorts formed on the basis of firm-specific attributes.
\end{abstract}

- JEL Classifications: E44, G32

- Key Words: Capital Structure, India, Panel Data, Adjustment Cost

\section{Introduction}

With ongoing liberalization of the Indian economy, including its financial

\footnotetext{
*Corresponding address: Basudeb Guha-Khasnobis, World Institute for Development Economics Research. The United Nations University, Katajanokanlaituri 6B, Helsinki 00160 Finland, Tel: +358-961599215, Fax: +358-9-61599333, E-mail: basudeb@wider.unu.edu

Saumitra N. Bhaduri, Indian Council for Research on International Economic Relations; Core 6A, $4^{\text {th }}$ Floor, India Habitat Centre Lodi Road; New Delhi 110003, India, Fax: $+91-11-4620180$, E-mail: bguh@icrier.res.in (C2002-Center for International Economics, Sejong Institution, All Rights Reserved.
} 
markets, firm level analyses of different corporate finance issues have started exerting a strong attraction for many scholars. In general, questions about the determination of the capital structure in developing countries are being increasingly examined since the early 90's due to the fast changing institutional framework in these countries. The move towards market oriented reforms in these countries has resulted in the widening and deepening of various financial markets, including the capital markets, presenting the corporate sectors the scope to choose their capital structures in an optimal fashion.

In recent years, a few studies, notably, Kunt-Demirguc and Maksimovic (1995), Singh (1995), and more recently, Booth et al. (2001) have started examining these issues. In a cross-country study Booth et al. (2001) have used a sample of 10 developing countries. In contrast to their predecessors, their study reveals that the factors pertaining to the issue of the determination of capital structure in the United States and the European countries are also potent enough in explaining financial decisions in developing countries despite the profound differences in the institutional framework in which they operate.

However, most of these existing studies on capital structures in developing countries are restricted in inference and scope due to the poor cross-sectional variation in data. The data set used for the Singh and Hamid study constitutes only the top 50 companies which might not be representative of the corporate sector in the developing countries, while Samuel (1996) and Cobham and Subramaniam (1998) used consolidated balance sheet data provided by the Reserve Bank of India and other financial institutions. Finally, Booth et al. (2001), which uses a sample of 100 top companies in ten developing countries also suffers from similar limitations in terms of cross sectional variation as well as the comprehensiveness of the data to construct those variables that are known to be relevant from earlier studies. Hence, despite the illuminating contributions of the recent researchers, the existing literature in modern finance still lacks adequate depth in empirical research on the issue of capital structure choice in less developed countries due to poor cross sectional variation in their relatively small samples.

More significantly, until recently, the corporate sectors of many developing countries were constrained on their choices of sources of funds. Access to the equity market was either highly regulated or limited by the underdeveloped stock markets. Developing country finance was dominated by development finance companies, which either through direct lending or through refinancing arrangements virtually monopolised the supply of debt finance to the corporate sector. 
Choice of capital structure was mainly norm driven. Against such a backdrop, findings of any empirical work on the capital structure could easily have been entirely constraint driven. A partially or completely unregulated financial market, which is essential for such research to be meaningful, was missing for many developing countries including India.

Until 1992, the Indian corporate sector faced many constraints on its choices regarding sources of funds. The Controller of Capital Issues (CCI) regulated access to the equity market and long-term debt was largely under the purview of the public sector Development Financial Institutions (DFI) which, either through direct lending or through refinancing arrangements, controlled the supply of debt finance to the corporate sector. In May 1992 the CCI was abolished and access to the equity market was made less restrictive, subject only to meeting certain technical conditions, and not to any formal approval process as had been the case earlier. On the debt front, institutional reform was less significant, in the sense that the DFI monolith remained virtually intact. However, some reforms took place in interest rate policy, with the institutions increasingly being given the freedom to determine the structure of their interest rates.

Therefore, beginning in May 1992, and increasing in scope over the next few years, the Indian corporate sector found itself facing a choice set of sources of finance that was closer to the stylized picture of an unrestricted capital market, particularly the equity market, that underpins the capital structure literature. This transition provides the basic motivation for this paper. Our interest is in knowing the following: Having transited from a relatively constrained to a relatively unconstrained financial regime, with an expanded choice set of sources of finance, how has the Indian corporate sector responded by way of capital restructuring ?

We take the approach of modelling the role of adjustment cost towards achieving the optimal capital structure. By introducing separate measures of short-term and long-term debt rather than an aggregate measure of total debt we take explicit account of the fact that some of the capital structure theories have different empirical implication with regard to the maturity structure of debt instruments.

\section{Analytical Framework}

Some of the empirical literature on capital structure ignores the possible dynamics in leverage decision by envisaging instantaneous (costless) adjustment 
towards the optimal capital structure. However, more realistically, adjustment costs could lead to lags in the process (e.g., Myers (1974); Fischer, Heinkel and Zechner (1989) and Hovakimian et al. (2001)). Therefore, one requires a dynamic setting to handle this issue. We set up a partial adjustment model to examine the non-instantaneous adjustment towards the optimal capital structure. However, it is also important to note that the more advanced approach to the issue could have been a cointegration specification, as it allows us to differentiate the long term adjustment from the short-term ones using time series data. Despite obvious advantages of that approach, we need to follow the later approach due to lack of sufficiently long time-series data to carry out meaningful estimation of a cointegration specification.

We specify our long term borrowing (LTB) behaviour model as follows:

$$
\left(l t d_{i t}-l t d_{i t-1}\right)=d\left(l t d_{i t}^{*}-l t d_{i t-1}\right) \text { and }\left(l t d_{i t}^{*}=x_{i t}^{\prime} \tilde{\beta}\right)+\tilde{v}_{i t}
$$

Here, ltd stands for actual long-term debt. A star over the variable denotes the (unobservable) optimal or desired level of the same. As argued, the existence of restructuring costs makes it costly for the firms to adopt the new desired capital structure immediately. In the partial adjustment specification $\delta,(0<\delta<1)$, is the coefficient of adjustment. The equation above postulates that the actual change $\left(l t d_{i t}-l t d_{i t-1}\right)$ in leverage in any given time period $t$ is some fraction $(\delta)$ of the desired change $\left(l t d_{i t}{ }^{*}-l t d_{i t-1}\right)$ for that period. If $\delta=1$, the actual leverage is equal to the desired level, or, in other words, the actual level adjusts to the desired level instantaneously an assumption that dominated the empirical capital structure literature since its inception. In contrast, our model explicitly takes into account the possibility of restructuring cost. In our model $\delta$ is expected to lie between zero and one, since adjustment to the desired leverage is likely to be incomplete in the presence of restructuring cost. The long run desired capital structure decision is modelled as a linear function of the vector $X_{i t}$, whose elements represent firm specific characteristics, suggested by alternative theories of capital structure. The disturbance term $v_{i t}$ has an error component structure specified as, $v_{i t}=\eta_{i}+\chi_{t}+v_{i t}$, where $\eta_{i}, \chi_{t}$ and $v_{i t}$ are time invariant firm specific, time specific and random errors respectively.

On substitution we get the following estimable reduced form:

$$
l t d_{i t}=\alpha l t d_{i t-1}+x_{i t}^{\prime} \beta+\mu_{i t} \text { where } \alpha=(1-\delta),(\beta=\delta \tilde{\beta}) \text { and } \mu_{i t}=\delta v_{i t}
$$


Similarly, the reduced form of short-term borrowing (STB) behaviour model can be defined as:

$$
s t b_{i t}=\alpha s t b_{i, t-1}+x_{i t}^{\prime} \beta+v_{i t}
$$

Compared to conventional time series averages of cross-sectional parameter estimates used in the literature, the panel data analysis used in this paper has three clear advantages. First, the panel data estimates are based on a large number of observations and hence more robust. Second, the combination of two dimensions potentially reduces the multi-collinearity problem. Third, it has the ability to control for omitted variables that are constant over time.

The general model of our type can be written as follows:

$$
Y_{i i t}=\sum_{k=1}^{q} \alpha_{K} Y_{i t-1}+\beta^{\prime} X_{i t}+\lambda_{t}+\eta_{i}+v_{i t}
$$

where $\left(t=q+1, \ldots, T_{i} ; i=1, \ldots N\right)$ and $\lambda_{t}$ and $\eta_{i}$ are the time specific and time invariant individual effects, $X_{i t}$ is the vector of explanatory variables and $q$ is the maximum lag in the model (which is one in our case). The $v_{i t}$ 's are assumed to be iids with zero mean, but any arbitrary form of hetroskedasticity across unit and time is also possible.

One can write the $T_{i}$ equation for individual $i$ as follows:

$$
Y_{i}=W_{i} \delta+v_{i} \eta_{i}+\mu_{i}
$$

where $\delta$ is a parameter vector including the $\alpha$, the $\beta$ 's and $\chi$ 's and $W_{i}$ is the data matrix, $v_{I}$ is a $T_{I} \times 1$ vector of one.

Now the standard GMM estimator of $\delta$ is as follows:

$$
\widehat{\delta}=\left[\left(\sum_{i} w_{i}^{* \prime} Z_{i}\right) A_{N}\left(\sum_{i} Z_{i}^{\prime} W_{i}^{*}\right)\right]^{-1}\left(\sum_{i} W_{i}^{\prime} Z_{i}\right) A_{N}\left(\sum_{i} Z_{i}^{\prime} y_{i}^{*}\right)
$$

where

$$
A_{N}=\left(\frac{1}{N} \sum_{i} Z_{i}^{\prime} H_{i} Z_{i}\right)^{-1}
$$

$W_{i}{ }^{*}$ and $y_{i}{ }^{*}$ are some transformations of $W_{i}$ and $y_{i}$. (these transformations can be first difference, within group etc.). In the above specification $Z_{I}$ is a matrix 
instrumental variable and $\mathrm{H}_{\mathrm{I}}$ is an individual specific weighting matrix.

If $Z_{i}=W_{i}^{*}$ and the transformations are from individual means, $\delta$ gives the within group estimator. Note that if $W_{i}^{*}$ contains the lagged dependent variables, within group estimators are not consistent for small $N$ (Allerano and Bond (1988)). Therefore, as our model contains the lagged dependent variable we need to estimate the borrowing behaviour equation using Generalised Methods of Moments ${ }^{1}$ technique by selecting appropriate lagged variables as instruments. In order to eliminate time invariant firm specific characteristics we estimate the equation in first differences. Assuming that the idiosyncratic component of the error is serially uncorrelated in the level equation, this will generate an error with moving average structure of order one in the equation in difference, so that oncelagged variables are also correlated with error term. However values of the regressor lagged twice or more will be legitimate instruments. Therefore, the estimation is done by using two or more lagged values of leverage as instruments. A complete specification of the instruments used in this paper is given in the appendix. We also carried out two specification tests to check for the validity of the assumption embedded in the model, viz., test on both first (AR-1) and second order (AR-2) serial correlation of the residuals and Sargan test of the correlation of the instruments with error term. The Sargan test of overidentifying restriction tries to test the optimality of $A_{N}$ for a given $Z_{i}$. The null hypothesis is the validity of the instruments (Allerano and Bond (1988)). The paper only reports two step estimates after correcting for unknown forms of hetroscadasticity.

\section{Sample and Variables}

The data for this analysis are drawn from the Centre for Monitoring Indian Economy (CMIE) Prowess database. It reports balance sheet data for a large number of Indian firms. The data set comprises a balanced panel of 697 manufacturing and non-financial firms over the period 1990-1998. All data used in this paper are based on annual balance sheet information reported by the firms. Descriptive statistics are presented in Table 1 (Appendix). It is noteworthy that although the sample covers a wide range of industries and has adequate variation across size, age and ownership structure, any conclusion that we make should be seen in the context that ours is not a totally random sample.

Before undertaking any investigation of capital structure, one needs to clearly

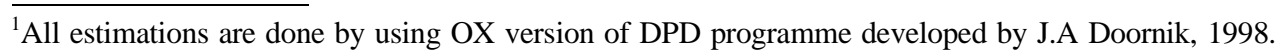


Table 1. Summary Statistics for the total sample of 697 Indian corporate firms over 1990-98.

\begin{tabular}{l|ccc}
\hline & MEAN & MEDIAN & ST. DEV \\
\hline LTB & 0.21 & 0.18 & 0.16 \\
STB & 0.20 & 0.18 & 0.15 \\
GFA & 0.60 & 0.59 & 0.27 \\
SIZE & 3.96 & 3.83 & 1.32 \\
DIVI & 0.27 & 0.24 & 0.51 \\
NDTS & 0.19 & 0.14 & 1.02 \\
CR & 0.62 & 0.65 & 0.18 \\
PROF & 0.12 & 0.12 & 0.08 \\
\hline
\end{tabular}

define the term. The definition of capital structure usually depends on the objective of the analysis. Since the objective of this paper is exploratory, we use the most acceptable (as well as broadest possible) definition of capital structure the ratio of debts to total assets - which is an indicator of the structure of claims on a firm. If the ratio is 0.5 , then one could interpret that half of the value of the asset is being owed to the creditors ${ }^{2}$.

As mentioned earlier, we have used both the ratios of book values of long-term and short-term debt to book values of total assets (defined as LTB and STB respectively) of the firms as our dependent variables. Thus, we explicitly account for the fact that some of the capital structure theories have different empirical implication with regard to the maturity structure of debt instruments ${ }^{3}$.

The variables that are used to explain the observed variation in debt levels are asset structure, firm size, dividend decision, non-debt tax shield, short-term financial distress risk and profitability. The potential roles of each variable in affecting the debt level are discussed below.

\section{A. Asset Structure}

Both the asymmetric information and agency cost theories of capital structure have suggested that the type of asset owned by a firm can affect its capital structure choice. According to the agency cost theory, (e.g., Galai and Masulis (1976), Jensen and Meckling (1976) and Myers (1977) to name a few) the shareholder of the leveraged firm has a tendency to invest sub-optimally to expropriate the wealth from the existing debt holders. These possibilities are known as "bondholder wealth expropriation" and "asset substitution" problems. If the debt market is characterised by rational agents, then one would expect debtors to charge a

${ }^{2}$ It is important to note that one minus the ratio represents the claims of the equity holders. 
premium over interest to protect themselves against such asset substitution problem. However, if the firm has collateralizable assets, then borrowers can be restricted from practising such asset substitution. Thus, for a firm with enough collaterizable assets, debt would be a cheaper instrument to use to raise money since it will attract lesser asset substitution premium. This feature may induce a positive association between collateralizable asset and debt.

Another agency problem between shareholder and managers arises from the tendency of managers to consume more than the optimal levels of perquisites, thereby reducing the value of the firm. Grossman and Hart (1982) suggested that firms with less collateralizable assets are more vulnerable to such agency cost since monitoring the capital outlays for such firms are more difficult and hence take more debt to mitigate such agency problems. Therefore, they suggested a negative association between leverage and collateralizable assets.

In the presence of asymmetric information between insiders (manager) and outsiders (stakeholders), managers may find it difficult to raise money from outside as creditors may demand more favourable terms to hedge against the possibility of managers funding bad projects. Thus, the firm might find it advantageous to sell secured debt as it reduces the information premium. The ratio of gross fixed asset to total asset (GFA) is used as a proxy to capture asset structure of the firm.

\section{B. Size}

There are several reasons to include firm size as a determinant of firm capital structure. Given the fact that large firms are likely to be more diversified and hence less prone to financial distress, one would expect a positive association between size and leverage decision. A number of authors (e.g., Warner (1977); Ang, Chua and McConnell (1982)) also suggested that direct financial distress cost is inversely related to firm size. Moreover, if the capital market is characterised by transaction costs associated with issue of new shares, one might expect size to play an important role in determining capital structure. Smith (1977) argues that as small firms pay much more than large firm to issue equity, they tend to be more leveraged. The natural logarithm of total asset (SIZE) is used as a proxy of size.

\section{Dividend Payout Decision}

As mentioned earlier, the degree of asymmetric information is a potentially

${ }^{3}$ Only book values are readily available. 
important determinant of capital structure decision. However, if a firm has some credible way of signaling the market regarding their quality, they can avoid such information premium and access the external sources of fund, particularly the equity market. One such proxy to capture the signalling content is the dividend payout ratio (DIVI). Some studies (e.g., John and Williams (1985); Miller and Rock (1985)) have argued that dividends are used as a signal of earnings and a firm with a reputation of dividend payment faces lesser asymmetric information related problems in accessing equity market ${ }^{4}$. On the other hand, if dividend payment represents a signal of better financial health and hence more debt taking capacity, we would expect a positive association.

\section{Non-Debt Tax Shield}

De Angelo and Masulis (1980) in their model showed that a firm's effective marginal tax rate on interest deduction depends on the firm's non-debt tax shields. They argue that non-debt tax shield is a substitute for the tax benefit of debt financing. Thus a firm with a large non-debt tax shield is likely to be less leveraged. However the identification and measurement of non-debt tax shield is somewhat problematic. Several proxies like depreciation, tax loss carry forward and investment tax credits are used to capture this effect. We have used Boyle's (1997) non debt tax shield measure as it accounts for the fact that the relationship between debt use and non debt tax shield should exist only for the subset of firms with a positive probability of tax exhaustion ${ }^{5}$. The proxy used for the non-debt tax shield (NDTS) is given by:

\section{NDTS=(Depreciation Taxes)/EBIT}

\section{E. Short-term Financial Distress Cost}

As debt involves a commitment of periodic payments, firms with weak liquidity positions are vulnerable to financial distress costs in a near bankruptcy situation. Therefore short-term liquidity position can be an important determinant of capital structure, a point also made by Lucas et al. (1996). The proxy used to study the influence of short-term financial distress risk on leverage is current ratio (CR)

\footnotetext{
${ }^{4}$ However such negative association could also be because of a high correlation between past profitability and dividend payment.

${ }^{5}$ This point was made by MacKie-Mason (1990).
} 
defined as a ratio of current asset to total asset.

\section{F. Profitability}

Pecking order theory proposed by Myers and Majluf (1984) postulates that if managers do not have any credible way of conveying inside information to the outsiders then they might prefer raising capital first from retained earning, second from debt and then from equity market as last resort to avoid information premium. Since profitable firms are also likely to have more retained earnings we would expect a negative association between leverage and past profitability. On the other hand, the static trade-off theory envisages a positive relation between profitability and leverage because a firm with high profits would require more tax shelter and they also have more debt taking capacities.

Table 2. GMM estimates of long term borrowing behaviour model. Dependent Variable: LTB

\begin{tabular}{l|clcc}
\hline \multicolumn{1}{c|}{ Variables } & Coefficient & Std . Error & T-statistic & P-value \\
\hline LTB(-1) & 0.771008 & 0.046889 & $16.443^{*}$ & 0.00 \\
GFA & 0.111149 & 0.056865 & $1.9546^{*}$ & 0.05 \\
SIZE & 0.000951 & 0.016299 & 0.05836 & 0.95 \\
DIVP & -0.00328 & 0.0026 & -1.2621 & 0.20 \\
NDTS & -0.00181 & 0.001654 & -1.0972 & 0.27 \\
CR & 0.059494 & 0.083824 & 0.70975 & 0.47 \\
PROF & -0.27775 & 0.041109 & $-6.7565^{*}$ & 0.00 \\
Constant & 0.007112 & 0.005536 & 1.2845 & 0.19 \\
1992-93 & -0.01093 & 0.007716 & -1.416 & 0.15 \\
1993-94 & -0.02009 & 0.006075 & $-3.3074^{*}$ & 0.00 \\
1994-95 & -0.00584 & 0.006263 & -0.93295 & 0.35 \\
Wald (joint) & 371.42 & & & 0.00 \\
Wald (dummy) & 12.366 & & & 0.01 \\
Sargan test & 9.4440 & & & 0.39 \\
AR(1) test: & -8.7265 & & & 0.00 \\
AR(2) test: & 1.7458 & & & 0.07 \\
\hline
\end{tabular}

Notes: All variables are in first difference. Symbol * denotes significance at 5\% level. Basic Instrument set used in this study is of the following form.

$$
Z_{i}=\left[\begin{array}{ccccccccccc}
l t d_{i 1} & 0 & 0 & 0 & \ldots & 0 & \ldots & \ldots & 0 & \vdots & \Delta x_{i 3}^{\prime} \\
0 & l t d_{i 1} & l t d_{i 2} & 0 & & 0 & & & 0 & \vdots & \Delta x_{i 4}^{\prime} \\
\vdots & 0 & 0 & & & \ddots & & & & \vdots & \vdots \\
0 & 0 & 0 & 0 & \ldots & l t d_{i 1} & \ldots & \ldots & l t d_{i 6} & \vdots & \Delta x_{i 6}^{\prime}
\end{array}\right] 1999
$$


Table 3. GMM estimates of short term borrowing behaviour model Dependent Variable: STB

\begin{tabular}{l|rlcc}
\hline \multicolumn{1}{c|}{ Variables } & Coefficient & Std .Error & T-statistic & P-value \\
\hline STB(-1) & 0.379186 & 0.05608 & $6.7615^{*}$ & 0.00 \\
GFA & 0.099347 & 0.060364 & $1.6458^{* *}$ & 0.09 \\
SIZE & -0.04142 & 0.014936 & $-2.7729^{*}$ & 0.00 \\
DIVP & -0.00205 & 0.002629 & -0.78027 & 0.43 \\
NDTS & 0.00104 & 0.001372 & 0.757813 & 0.44 \\
CR & 0.164959 & 0.058417 & $2.8238^{*}$ & 0.00 \\
PROF & -0.21267 & 0.053867 & $-3.9481^{*}$ & 0.00 \\
Constant & 0.002194 & 0.004474 & 0.49047 & 0.62 \\
1992-93 & 0.007535 & 0.006382 & 1.1806 & 0.23 \\
1993-94 & -0.00294 & 0.005069 & -0.58038 & 0.56 \\
1994-95 & 0.012848 & 0.005101 & $2.5185^{*}$ & 0.01 \\
Wald (joint) & 89.901 & & & 0.00 \\
Wald (dummy) & 12.282 & & & 0.01 \\
Sargan test & 10.498 & & & 0.31 \\
AR(1) test: & -7.3338 & & & 0.00 \\
AR(2) test: & -0.7034 & & & 0.48 \\
\hline
\end{tabular}

Notes: All variables are in first difference. Symbol $*$ denotes significance at $5 \%$ level and $* *$ denotes significance at $10 \%$ level.

Therefore, presence of both these effects makes the total effect of profitability on leverage theoretically ambiguous and needs empirical verification. The ratio of earning before tax and interest payments to total asset (PROF) is used as a proxy of profitability.

\section{Discussion of Results}

Tables 2 and 3 report the GMM estimates of the long term and short-term borrowing behaviour models, respectively. The estimated coefficient of the lagged leverage variable ranges between zero and one, indicating the possibility of costly adjustment towards optimal capital structure. We also find that the estimated coefficient on lagged leverage is much higher for long term borrowing than the short-term one (more than twice). Thus, in terms of speed of adjustment towards of optimal capital structure, which is defined as $(1-\alpha)$, the long-term debt model shows a much slower rate than that of short term one. For long term debt the actual change in leverage is only $22 \%$ of the desired change, while for the short term one the corresponding figure is as high as $66 \%$. 
The capital structure decision in our sample of Indian manufacturing firms is significantly influenced by factors such as size, asset structure, profitability and short-term financial distress cost. The coefficient on the size variable for the short term borrowing model is of the expected sign indicating the fact that small firms depend more on the short-term borrowings probably because of the high transaction and information cost faced by them in raising long-term debt. However, the coefficient on the size variable in long term model is insignificant. The coefficients on the profitability variable are significant and negative $(-0.27$ and 0.21) for long term and short term borrowing, respectively. These negative significant coefficients on profitability are consistent with the pecking order hypothesis that firms prefer internal to external sources of finance. Assets structure variable turns out to be significant in all cases corroborating the collateral value hypothesis. The coefficients are 0.11 and 0.09 respectively. Finally, short-term financial distress risk is negatively related with the leverage decision. However, it is significant for the short-term model and not for the long term borrowing one. Since CR captures short-term financial distress risk (a high CR implies low distress cost) one would expect this to be a more meaningful determinant for the short term borrowing behaviour and not for the long term one. For long term model, volatility of operating income or sales would have been a more appropriate proxy for longterm distress risk. Unfortunately, we could not use these variables due to data limitation.

We do not find any strong evidence in favour of dividend decision and non-debt tax shield hypotheses. Turning to the test statistics, neither the AR-2 statistics nor the Sargan tests suggest the presence of serially correlated errors in any of the cases.

Finally, it is important to contrast our results with that of Booth et al. (2001). Notwithstanding the limitation of IFC data used by Booth et al., both in terms of company coverage and lack of sufficient information to construct many variables ${ }^{6}$ that are known to be relevant from studies of firms in developed countries, their results are similar to ours in terms of statistically significant factors influencing the optimal capital structure choice. Similar to Booth et al. our paper also provides evidence that the optimal capital structure choice in developing countries are strongly influenced by the factors like size, asset structure, profitability and shortterm financial distress cost. To the extent that our study adequately controls for

${ }^{6}$ The proxies related to tax rate, dividend payment behaviour and both short-term and long term business risk are not captured in Booth et al (2001) due to lack of data. 
the possible sources of differentiation among firms in their optimisation choices and incorporates relevant variables that was missing in the earlier studies, it provides more robust insight into the validity for the Indian firms of various mainstream capital structure theories.

\section{Determinants of Speed of Adjustment: Cohort Analysis}

Having established the general pattern of adjustment speeds for the whole sample of 697 firms we formed smaller cohorts based on age, size, and group affiliation to detect if there are significant differences in adjustment speeds between the cohorts. The speed of adjustment towards the optimal capital structure depends on a set of variables, which may or may not be identical to those affecting the optimal debt level. In the case of determinants of speed of adjustment the focus is more on the costs of changing from existing capital structure to optimal one rather than on the costs associated with leverage level. We used four alternative ways of forming smaller cohorts according to the size of the firm, age of the firm, possible association with a business group and the expected growth of the firm.

If changing capital structure involves fixed costs, they will be proportionately smaller for larger and more matured firms. Further, large and matured firms may find it easier to access capital, be it equity or debt, due to more information being available about them. Therefore we can expect to find firm size and age to be positively associated with the speed of adjustment.

Similarly, a growing firm may find it easier to change its capital structure by choosing the source and composition of the new capital it raises. Even under asymmetric information, these firms are less likely to attract information premium, due to the positive effect of growth opportunity. For example, in order to reduce leverage a growing firm can get rid of its internal slack and thus avoid the negative signal of raising funds from external sources. Hence we would expect firms with higher growth opportunity to adjust faster towards their optimal capital structure than slow growth firms. Further, the greater the growth opportunity, the greater is the probability that the firm will require external funds. If the major part of the costs of raising external finance were fixed, then the higher growth firms might find it less expensive to adjust towards the optimal capital structure. Finally, firms that are associated with a business group, are known to have better access to sources of funds, and hence, are expected to move faster towards their optimal capital structures. 
Table 4. Results of segmentation analysis according to various firm specific attributes for long term borrowings (LTB) (annual speed of adjustments reported in the table are in \%)

\begin{tabular}{c|ccccc}
\hline & Quartile 1 & Quartile 2 & Quartile 3 & Quartile 4 & Full Sample \\
\hline SIZE $(13,25,41)$ & 30 & 41 & 24 & 14 & 22 \\
AGE $(19.45,41.72,103.69)$ & 31 & 23 & 38 & 56 & 22 \\
Growth $(8.8,18.73,32.55)$ & 8 & 28 & 34 & 37 & 22 \\
\hline
\end{tabular}

Note: Figures in the parentheses denote the quartile values, respectively. The figures in the cells denote the speeds of adjustment.

In order to differentiate firms by the size, age and the expected growth of firms, the value of total asset on 1993, age of the firm on 1993 and growth total assets between 1990-93 are used, respectively. Specifically, in a sub-sample analysis, we have used the quartile distribution of each of these segmentation variables to check our hypothesis whether the speed of adjustment towards the optimal capital structure varies systematically across firm specific attributes or not. The following box reports the results of our segmentation analysis for long term borrowings, as the cost of adjustments are likely to be more significant for the long term borrowing than the short term ones. However, we have also conducted similar exercise for the short-term borrowings and, as expected, the results do not show any obvious association between speed of adjustment and the firm specific attributes.

The segmentation analysis results reported above show a positive association between the speed of adjustment towards the optimal capital structure and the age and growth of the firm. This lends support to our hypothesis that the growing and the matured firm may find it easier to change its capital structure due the less asymmetric information related problems that they face while raising new capital. However, the association between the speed of adjustment and size of the firm is negative and apparently contrary to received wisdom. One possible explanation for such counter intuitive result could be a particular institutional feature of many developing countries including India, where strong Government intervention in the credit allocation process allows young firms to receive preferential treatment in terms of access to credit.

\section{Conclusions}

The dynamic panel data model used in this paper suggests a possibility of costly restructuring for the Indian firms and differential costs of adjustment for long term and short-term borrowing. The speed of adjustment towards optimal capital 
structure is much higher for the short term borrowing than the long term one. The evidence presented in this paper also brings certain regularities that are consistent with findings in the existing literature on capital structure. The paper suggests a possibility of optimal capital structure strongly influenced by factor the factors like size, asset structure, profitability and short-term financial distress cost.

Received 29 March 2001; Accepted 30 July 2002

\section{References}

Arellano, M. and Bond, S. (1988), Dynamic Panel Data Estimation Using DPD A Guide For User, IFS Working Paper No.88/15.

Ang, J., Chua, J., and McConnell, J. (1982), The Administrative Costs of Corporate Bankruptcy: A Note, Journal of Finance, 37, 219-26.

Booth, L., Aivazian, V., Kunt-Demirguc, A. and Maksimovic, V. (2001), Capital Structure in Developing Countries, Journal of Finance, 56, 1, 87-130.

Boyle, G, and Eckhold, K. (1997), Capital Structure Choice and Financial Market Liberalization: Evidence from New Zealand, Applied Financial Economics, 7, 427437.

DeAngelo, H. and Masulis, R. (1980), Optimal Capital Structure under Corporate and Personal Taxation, Journal of Financial Economics, 8, 3-29.

Fischer, E. O., Heinkel, R. and Zechner, J. (1989), Dynamic Capital Structure Choice: Theory and Test, Journal of Finance, 44, 19-40.

Grossman, S. and Hart, O. (1982), Corporate Financial Structure and Managerial Incentives, In J.McCall (ed.), The Economics of Information and Uncertainty. Chicago: University of Chicago Press.

Hovakimian, A., Opler, T., and Titman, S. (2001), The Debt- Equity Choice, Journal of Financial and Quantitative Analysis.

Jensen, M. and Meckling, W. (1976), Theory of the Firm: Managerial Behavior, Agency Costs and Ownership Structure, Journal of Financial Economics, 3, 305-60.

Kunt, A.D and Maskimovic, V. (1995), Stock market development and firm financing choice, World Bank Policy Research Working Paper, No.1461.

Lucas, A., Dijk, R., and Kloek, T. (1996), Outlier Robust GMM Estimation of Leverage Determinants in Linear Dynamic Panel Data Models, Unpublished paper.

Miller, M., and Rock, K. (1985), Dividend Policy Under Asymmetric Information, Journal of Finance, 40, 1031-51.

Myers, S. C. (1974), Interaction of Corporate Financing and Investment Decision Implication for Capital Budgeting, Journal of Finance, 24, 1-25.

Myers, S. C. (1977), Determinants of Corporate Borrowing, Journal of Financial Economics, 9, 147-76. 
Myers, S.C, and Majluf, N. (1984), Corporate Financing and Investment Decisions When Firms Have Information Investors Do Not Have, Journal of Financial Economics, 13, 187-221.

Singh, A. (1995), Corporate Financing Patterns in Industrializing Economics: A Comparative International Study, Technical Paper 2, and International Finance Corporation.

Smith, C. (1977), Alternative Methods for Raising Capital: Rights versus Underwritten Offerings, Journal of Financial Economics, 5, 273-307.

Warner, J. (1977), Bankruptcy Costs: Some Evidence, Journal of Finance, 32, 337-47. 